\title{
THE INTERNET AND ELT: COSTS, GAINS AND COMPROMISES
}

\author{
REBECA UNGUREANU
}

\begin{abstract}
:
The paper analyzes some present and future trends in education, zooming in on the English class, through the impact of the most influential product of the human mind, the Internet. Extensive research is currently being done on the roles of the Internet upon our society, with special emphasis on education. I follow some of these research projects' threads and offer up-to-date insights into the debates and controversies the Internet has awoken. As a result of scanning some of the future educational trends, the conclusion I draw is that of an obvious compromise the English teacher has to sign: teaching both classical and modern competencies but learning to use the digital language of today's generation, while not overlooking the students' emotional needs.
\end{abstract}

Keywords: ICT, digital literacy, Digital Natives, adaptation, blended learning.

\section{Introduction}

The Internet is ubiquitous. Today's students surf the Internet non-stop, in or out of school. There is therefore an obvious need to study what has become the major medium of communication and attraction for all ages and how it impacts the educational environment.

The first to be tackled is a study of the digital mural of today's society, as painted by the development of media and technology. To follow, is a description of what education has evolved into, due to the same factors, and what facilities and drawbacks it has brought along both to the process of teaching and to its participators, teachers and students alike. The main points of the discussion will be the digital versus print debate, the description and analysis of what our generation of students have been called, that is, Digital Natives, as well as the specific gains and costs of introducing the Internet into the classroom. In the end, the conclusions will deal with the so-called "compromise" between what still is, in most of our schools, formal learning, and the future of elearning, as seen in the digital projects being already applied in different parts of the world. Moreover, if the Internet, the social networks (such as Facebook) are actively involved in our daily routine, which involves and affects the educational environment directly, then not only training in digital literacy is needed, but also training in emotional intelligence and time management should be part of the picture as well. 


\section{The wide web world we live in}

What Romanian communism has in common with the World Wide Web is the temporal platform on which the first died and the latter was born. If the first is mostly associated with oppression and autocracy, the second could only be linked to democracy and freedom. One year in history, two collosal national and international events. Despite the gigantic chasm between the two, their importance weighs heavy in terms of their impact and aftermath.

But to start with, media and technology are nowadays part of every social class's life. Even in some of the third-world countries, in slums, in rural areas, in remote areas, in the tents of nomad people, connection with the other continents takes place: there are TV sets, cellphones and the Internet.

Media and technology have ruined traditions and have set different ideals. But, with the ruining, they made something work more easily. Did it deserve the cost? In some situations where life was at stake everybody will say it did. But, paradoxically, people will complain of the distance media and technology have created in human interaction and relationships.

We live in the world of smartphones, Macs and Facebook, more in front of screens than off-screen, be it those of television sets, computer monitors or mobile phones. The very young can handle the touchscreen so naturally that we wonder what the standard of skilfulness will become. We have grown up with English cartoons. Nowadays some cartoons are dubbed, but there are always movie series to download, on-line games, networks and websites that may foster practice of the English language.

According to Nicholas Carr, in The Shallows: How the Internet is changing the way we think, read and remember, a 2011 Pulitzer Prize nominee, the Internet demonstrated its practicality in so many domains that we face acted naturally towards its expansion, without putting some time aside to question the media revolution taking place all around ous, in our homes, our workplaces, our schools. Before the Internet, the media had been divided into fragments: books and newspapers, radios, telephones, phonographs, calculator, encyclopedias, which once digitized are no longer divided. These old technologies will still be used in the future but they will lose their economic and cultural force, as they have already started to.

It is in the digital files our future of knowledge and culture will lie. One of the costs of the Internet absorption is that it does not only reshape traditional media but also changes the way we use the content within, the way we experience and understand it (23).

To demonstrate the fast paced rhythm at which the Internet managed to have the world moving, there comes the practical evidence of figures (from statistics' websites census.gov/popclock/, worldometers.info/ro/, internetworldstats.com): of the 7,118,591,800 world population, 2,538,866,474 
are Internet users. Some sources argue that a number of 474 people is added each day, which does not leave too much room for imagination, but rather to approximation as far as digital literacy is concerned. At the end of each day, more than 400 billion of e-mails will have been sent, and more than 4 million blog posts will have been posted. Google boasts a number of more than 4 billion searches per day and Facebook has long bragged about its first billion users, with the number ever growing.

In June 2012, 21.6\% of the Internet users are from Europe. In Romania, of the 21 million inhabitants, 9.6 are also familiar with the "habitat" of the Internet.

What keeps people on the Internet? What interest dictates the amount of time they alot to the online environment? As well-known sites in the field display, the top websites worldwide are: 1. Facebook, 2.Google, 3.YouTube, 4.Yahoo, 5.Baidu, 6.Wikipedia, 7.Amazon, 8.QQ, 9. Windows Live, 10. Taobao, with Baidu, QQ and Taobao being all developed and used by the Chinese (Alexa.com).

As far as Romania is concerned, the sequence varies slightly in the first part, with Google.ro occupying the first place, followed by 2.Facebook and 3.Google.com. The follow-up is somehow predictable, 4.Youtube, 5.Yahoo, except for 6.Neobux, whose presence in the top ten I personally find striking. Its welcoming message reads: "Now you can multiply your earnings just by viewing advertisements. At NeoBux you get paid just for browsing our advertisers' websites." The last most accessed four sites by the Romanians are: 7. Wikipedia, 8.Wordpress, 9.Filelist, and 10.Realitatea.

The conclusion to be drawn following the figures and the websites displayed is that the Internet is deeply ingrained in our day-to-day life and culture. The first website most accessed worldwide is a social network, which bears witness to the fact that the utmost needs of human kind, after the physiological and safety ones, are the desire for a sense of love, belongingness and self-esteem. To follow is Google, which used to be in the top a year ago, as Alexa.com evaluated. The world "googles" to satisfy its need of information. Google makes the world's information available and accessible in less than a second, which leads to our generation's need to be trained how to filter the online materials, which amount to hundreds of millions. If school used to be the highest ranked environment associated with knowledge gain, nowadays the appreciation of school as the most important knowledge provider has dwindled, since so much of the knowledge has been transferred unto the digital environment. Online schools and courses have given various people opportunities to obtain the qualification they needed to start a career or to extend their studies. The other websites in the row testify to and serve the other needs of people, that is, the sharing of goods, along with all the advertising and all possible options of financial transactions implied. 
On the grounds of analyzing the lists of the most popular websites in the world it is but logical to state that the Internet represents and acts as a source of news, facts, and figures, a communication tool allowing people to connect with anyone, anytime, anywhere, as well as a way to advertise, invest and shop, while also playing the role of an educational tool and a massive entertainment platform. As it was noted by David Crystal, world-renowned linguist and writer, the emphasis of the Internet has shifted from technology to people and purposes, therefore is now seen more through a social perspective (IV).

The issue given rise to by the fast speed of Internet penetration worldwide and, implicitly, the growing number of materials being transferred to or created in the digital environment, is the two-way effects this present digital shift has, particularly on the human abilities of reading and writing.

\section{Print vs. digital debate}

Impacting the field of education inside and outside the school environment and people of all ages, but especially the younger, is the much debated situation of the hegemonoy of digital over the print.

Before the Oxford-educated computer scientist Tim Berners-Lee introduced the World Wide Web in 1989, the media was divided into fragments, which, once digitized, lose their fragmentariness. The novelty around the digitalization of all media and sources of knowledge is that a single digital material turns into a multimedia palette. With more and more of our resources of information being moved online, a growth in the time we spend online has been one of the obvious consequences, to the detriment of the time we assign to reading print publications.

Firstly, the enormous benefit of this reality which is developing at an unprecedented speed, is that digital materials, and principally books, are cheaper and so much easier to store and share than the print ones. The gates being opened and the shortcuts paved for, the natural outcome is an unnatural volume of information bombarding the digital space, which together with the easier access, allows for practicality to be the main characteristic. There is also the constant update and possibility of editing and then of copying exactly the same document without degrading the quality as it is sometimes with printed files.

In addition, throughout the time spent online there are a number of skills that are practised and developed: the metacognitive and cognitive skills of browsing, scanning, keyword spotting, together with the improvement of the hand-eye coordination and reflex response. Finally, these are also carried out in multitasking, which is, undoubtedly, a great realisation, but which does not always result in better functioning, in creativity or increased productivity.

The Internet also engages almost all of our senses except smell and taste at once, and acts like a mechanism of positive reinforcement. The psychologist 
B. F. Skinner, who coined the operant conditioning theory of behaviour based on reinforcement, would have certainly nodded his head in agreement: you click a link and you immediately are rewarded with new material to analyze and evaluate, with fresh social or intellectual food. The other side of the coin, shows, as expected, important costs at which the digital files are taking over the print ones.

To begin with, there are not any official codes of standards of quality and other values that permit for materials to be made public online. There is a limitless democracy which has fostered a tragic inability to discern the good from the less good and bad. The question is no longer how to get information, but about the strategies for coping with the information and the goals of using the information.

As for the experience of reading, it is completely altered by the change. $\mathrm{Html}$ pages prompt readers to turn to skimming more and lose their ability to read in depth, together with the patience to do it. But what research has demonstrated is that the reading of linear text helps people to comprehend more, remember more, and learn more than those who read digital files.

Many observers believe it is only a matter of time before socialnetworking functions are incorporated into digital readers, turning reading into something like a team sport. We'll chat and pass virtual notes while scanning electronic text. We'll subscribe to services that automatically update our e-books with comments and revisions added by fellow readers. "Soon", says Ben Vershbow of the Institute for the Future of the Book, "books will literally have discussions inside of them, both live chats and asynchronous exchanges through comments and social annotation. You will be able to see who else out there is reading that book and be able to open up a dialog with them" (Carr 32).

As far as writing is concerned, besides the popular Net language that is present in both production skills, authors have to adapt new trends and expectations that readers have. Some eloquent illustrations of such adaptions are the cell phone novels in Japan and "vooks" (e-books with embedded videos).

The age group that uses the Internet the most is gradually decreasing. Nowadays we can still witness the effects on our own, while the generations rising after us are directly born into the virtual space. If the young adults and the adults today stand as a link between the two ages - the print and the digital, and if our brains got to be trained differently, the younger generations will not have the chance to experiment the change and decide how much their skills will to be altered by it, but their skills and abilities will be educated to be different from the very beginning. 


\section{"Net generation" or the "digital natives" of the $21^{\text {st }}$ century}

Innovation seems to be constant nowadays and prompts the educational environment to adapt faster to the trend or else become irrelevant for the generation it teaches, and for the future generations.

The students of today, the Digital Natives, the N-gen (Net) or D-gen (digital), all speak the digital language of computers, video games and the Internet. On the other side of the spectrum, the ones who have recently learnt or are still learning this new language, among which, hopefully, a growing number of teachers, are known as the Digital Immigrants, as seen from the viewpoint of Mark Prensky (Digital Natives, Digital Immigrants, 2).

This freshly-made category of students is the first generation to grow up with technology literally surrounding them: computers, portable music players, video games, cell phones, Internet access. Step by step they have integrated their usage in every aspect of their lives and now as adolescents and college students, they carry a vast digital arsenal on them, consisting of all of the mentioned devices and the services they provide: downloaded music, e-books, instant messaging. Compared to the digital natives, the immigrants can be recognized from such characteristics as turning to the Internet as a second choice, printing out emails, printing documents that need editing, bringing people to physically see an interesting website rather than just sending them the URL, or the "Did you get my email?" phone call.

As it was noted by Prensky, the Digital natives are used to receiving information really fast, like to multi-task, prefer graphics to text, function best when networked, instantly gratified and frequently rewarded, prefer games to "serious" work (3). As for the Digital Immigrants, they do not consider that learning can take place succesfully while watching TV or listening to music, because they themselves find this impossible. This is the reason why Natives often blame their Digital Immigrant instructors for not making their education worth paying attention to. They do not have or do not want to have the same patience and focus for lectures and step-by-step logic as students in past generations used to have (5).

They find technology, or more specifically, the Internet, essential to education because it is part of their world, embedded in society, therefore it is difficult not to know how to use it. This makes things faster, abstract concepts easier to grasp, it allows learning about virtually any topic and enhances connection with peers or friends that can provide or be provided with help.

Still, students do not rely entirely on technology as their ideal learning tool or perfect substitute, but recognize and give credit to the human teacher tool, too. The Net Geners consider teachers still vital to the learning process, contending that computers could never replace humans. The most relevant 
argument to sustain this point of view is that learning is based on motivation and teachers are the main fosterers of motivation, from their perspective.

Research claims that individuals raised within a digital environment, with computers, deal differently with information, that is, they prefer learning through discovery rather than being told, making observations, formulating hypotheses, figuring out rules inductively and have a different distribution of attention, shifting from one task to another, with a fast response time. They are skillful, rapid, multi-task communicators. Due to the extended availability of visual media, Net Geners are more visually literate than the previous generations. They develop visual and spatial skills at the cost of text literacy, though. No one can question their ability to use a variety of IT devices and Web surfing expertise, but they might not be as knowledgeable when it comes to understanding technological facts and data. Other characteristics of the digitally savvy generation are: striking openness to diversity, differences, sharing, preference for peer-to-peer approach, orientation to achievement, preference for structure rather than ambiguity, craving for interaction and interactivity. Although more teachers and students around the world use online communication to offer support and exchange of ideas or just to keep in contact, the "constant glow of computer screen" (Oblinger 64) has left Net Gen students longing for more face-to-face interaction.

Researchers report Net Gen students will refuse to read large amounts of text, whether as a part of reading assignment or a lenghty instruction. Students retain 10 percent on average of what they read but up to 30 percent of what they see. They would refuse to process longer written directions but would rather infer or turn in incomplete assignments. It has been proved practically that given the same assignment but with the presentation of pictures first rather than words, students' scores gained 4-9 percent (Oblinger 25, 26). The "Talk, text, test" traditional manner of teaching and evaluation is not as effective anymore as it used to, since traditional classrooms do not have all the students interacting anyway, making the Internet more attractive.

As a conclusion, after dusting the picture of the Digital Natives and looking closer at their underlying characteristics, we realize the direction education should be taking, since these Digital Natives are today's and tomorrow's students.

\section{ELT and ICT}

Whether teachers and parents worldwide or in Romania like or dislike the Internet's growing reality, it is the most assured component of the future of humankind: it will not go back, it will never slacken, it will never stand still. As long as this reality is present in our lives, digital literacy will be an imperative in curricular and extra-curricular education. With more and more information being 
presented in electronic form, digital literacy will not stand just as a skill to be taught at school, but will develop into a life skill.

Information literacy, or digital literacy, is defined as "the ability to access, evaluate and use information from a variety of sources, to recognize when information is needed and to know how to learn" (Hering 74).

With more than half of the online content being in English only (56\%), it is wise to admit that this represents a need for English knowledge along with digital knowledge, but it also stands as the means to fulfil these needs. "One of the strongest arguments for using the Internet in the EFL classroom is the fact that it exposes the learner to authentic language" (G. Lewis 8).

The new challenge teachers are faced with and will sooner or later need to face, depeding on the school and its opennes to technology, is digital literacy and using it purposefully in the English class. At a slower or at a more rapid pace, the use of Internet or ICT (Information and Communication Technologies) in schools is growing. Even if there is a pressure on teachers to use it for curricular purposes, it should not spring from or result in "technological determinism", which is merely using technology thanks to its availability. We should resist the superficial tendency to do so, particularly where teachers already have an ICT lab assigned for their English class. Having students Google words, concepts, events and what else in the ICT lab is not enough, as James E. Herring believes. Herring, a lecturer in Teacher Librarianship at Charles Stuart University, Australia, states that if the Internet is seen simply as a recreational tool, for both teachers and students, we will have wasted the opportunity to use its potential for our good (2).

If ICT's role is to improve learning, then the issue teachers are faced with is not just to introduce ICT because of its availability, but based on educational criteria, and, more, on catering for the different styles of learning there are.

\section{Gains and costs}

To start the gains list is the fact that the Internet stands as a unique source of information and materials, then as a method of presenting content, as much as a platform to encourage students' collaboration. It also works as a communication and connection tool with other teachers around the world, and the community of ESL and EFL is not insignificant on the five continents. The predicted costs of the invading Internet in schools and in the English class are: more responsibility and stress as a result of the effort in ICT training and incorporation and the shift in the role of the classical teacher, who does not act like the 'sage on the stage' anymore, but learns how to be the 'guide on the side'. As for the students, the gains and costs are even greater in number and influence upon both their academic and personal lives. The list of benefits include accessibility, flexibility, 
collaboration, extended opportunities, motivation and, especially relevant, fun. To add to the list is ownership of learning, communication in and out of school, interactive teaching and learning resources, learning from home.

Costs, on the other hand, might, in some views, be weightier than the benefits, mainly because the Internet Addiction Disorder is one of them. While it is true that using the Internet in the English class might not necessarily lead to Internet addiction, it might support it nonetheless. Other shortcomings include the loss of self-motivation and discipline, anxiety to share knowledge, competition, loss of appropriate writing skills, unbalanced access to infrastructure and hardware, corrosion of critical and evaluation skills, and, from the social perspective, alienation and isolation. The Internet affects ethics and etiquette; it is viewed mainly as a source of entertainment, while it raises big questions regarding security. Also, it sometimes fosters superficiality and limited use of reflection, since almost everything is already thought out. It can be the greatest distractor, too. These enumerations of benefits and prejudices are the most common ones.

The challenge for teachers, however, is "to make the best use of the various features of the Internet in order to improve students' education, their own contribution to that education, and their own learning and professional development" ("Key Data", 22).

\section{Present and future trends in $21^{\text {st }}$ century learning}

With globalization moving closer to the core of conversations and considerations in all layers of society, educators need to ask themselves where society is heading and to provide practical answers to prepare children for successfully facing at least some of the aspects of the future world.

In Learning in the 21st Century, Jennifer Dorman, a CELTA-Certified ESOL Teacher and Keystone Technology Integrator, considers globalization as one of the societal changes, to which she adds shifting demographics, changing values and attitudes, and, of course, transformative technologies. Accordingly, the critical need for educational systems to fulfil is adaptation. Skills and knowledge required for civic life in the 21 st century are also shifting, work ethic, collaboration, good communication, social responsibility and critical and problem solving being emphasized almost to the same degrees. All of these can be harnessed and fostered in the EFL class through activities that tap the right part of the brain as well.

The vision for the $21^{\text {st }}$ century learning addresses three main skills: learning and thinking, ICT skills, and life skills. Learning and thinking skills refer to critical-thinking and problem-solving, communication, creativity and innovation, and contextual learning which can all be practised through and together with ICT skills. The life skills "required" from our students today are 
all based on the extent to which emotional intelligence is pursued, therefore it could be argued that leadership, ethics, accountability, adaptability, personal productivity, personal responsibility, people skills, self-directions and social responsibility are only facets of a greater emotional variable.

But these skills, which some of the schools in Europe have already implemented as part of their vision, are said to be more easily pursued through technology. For some it might be true, for others it might still seem like a farfetched product of the human imagination. Regardless of what some of the educators think, some schools in the USA have already taken action towards digital practicality: they have considered mobile devices not only a secondary means of delivering teaching and practising learning, but they have developed BYOD plans (Bring Your Own Device). BYOD plans are becoming a viable solution, since they sustain a practical, basically money-saving system, with students bringing their own laptops or tablets at school, to replace the traditional system of pen and paper resources and methods. This is a valid prospect especially because it has increasingly parental support, as we find out in Learning in the 21st Century: Mobile Devices + Social Media $=$ Personalized Learning (tomorrow.org).

Such are some of the plans of a number of school managers and teachers that will sooner or later be implemented. Sooner or later, these trends will become part of our systems as well and it should not find us unprepared.

\section{Building the bridge of compromise}

If we are to count the arguments for and against the integration of ICT in teaching and learning, and particularly, in teaching and learning English, and if we are also to consider our emotionally illiterate students, we need to build a solid bridge between traditional methodologies and modern trends. We cannot pretend to be blind to how the Internet is quickly gaining territory and cannot yield to it without facing it. Neither do we have to imagine robots taking over our jobs, but we have to be flexible enough to see the need for a compromise. The human teacher still holds a strong position thanks to life experience, which cannot be counterfeited. However, education today, ELT included, depends on the teacher's ability to complement and conciliate face-to-face learning with online learning through managing new technologies, curricula, online resources and methods of delivery, while ensuring that the emotional needs of the students are not overlooked, but catered for. The result is what specialists have called "blended learning", to which activities that help students know themselves and the others better can be added.

David Gordon Smith and Erich Baberowsky in Teaching English with Information Technology provide some very good and relevant examples of CALL (Computer Assisted Language Learning) practice which we are going to 
reproduce here. The first one is the use of e-mail for feedback, story-writing, information-gathering, jigsaw activities, role-plays and YahooGroups (17).

A plethora of other resources can be drawn from the Internet, such as music and practice based on lyrics, information and exercises based on celebrities and famous people, all shared with the class. A final activity could be a quiz derived from all the information shared in the class or a quiz the students would have to complete after searching the web for specific pieces of information.

Other uses of the Internet in the English class include:

- EFL/TESOL websites, that offer a wide range of exercises and activities

- Music: a teacher can use videos and lyrics to make up exercises

- Film and music reviews, IMDB (Internet Movie Data Base) providing a variety of reviews which can be the start-up point of diverse exercises

- Job advertisements: students can mix up characteristics of job descriptions in English and work in groups to guess what the job was

- Holidays: students can be encouraged to search for the ideal holiday package and present it to the class

- History: the Internet offers rich amounts of information on English and American history which the teacher can use in exercises such as suggesting students to search for the most unusual moves in the history of English-speaking countries and discuss them in class, through using debates

- Poetry

- News

- Online Magazines

- Explanations on how to use certain objects; directions; guides

- Sports: it might be interesting, especially for boys, to follow what Manchester United's activity has been for the last 30 years, while girls can search for behind stories of English or American gymnasts who won the Olympics

- Companies: students can be suggested to look for the history of great American or English companies on the market today. For the Facebook addicts or fans, alternatives could be improvised, as seen in Facebooking without facebook, which offers hands-on possibilities to the social network, which are to the kinesthetic learners' like. To start with, paper profiles can be stuck around the room for students to read and comment on, as can projects, homework and any work for students to "like" and or comment on. Students can create a classical group interest page, that is, a poster on a specific topic, either picked from a list or picked by themselves, which can be added to through the term. 


\section{Using students' own gagdgetry}

Paul Ashe, EFL teacher, comes up with a very attractive alternative: personalising learning. His solutions are building activities around using mobile phones, cameras, mp3s, photos and videos that belong to students. Some examples are: taking the mobile phones out and discussing in pairs where and how they got it, why, for how long, and then report back to the class about their partner's phone. This activity practises the past simple, present perfect simple, and reported speech.

- Mobiles and text messaging. The teacher can also have a special lesson on text messaging language, with the analysis of some pieces written by natives. If a teacher wants to add some music to it, an Eurovision ring tone contest can take place, with the opportunity for the class to offer feedback and vote the best ring tone.

- Photo projects. Also, photo projects can be engaging students in meaningful learning. Learners can be asked to take photos of themselves at each stage of their daily routine and then to bring the photos to class. They can use them to describe their daily routine or try to put a partner's photos in order and write sentences to describe their routine, or, to make it more funny, they can write totally opposite or funny descriptions of the pictures.

- Tracking English ads and news in town. Another hands-on, or eyeson, activity is to ask the learners to keep an eye out for things in English around town. Nowadays, with this phenomenon getting bigger, the project can be repeated on a monthly basis.

- Class newspaper. Learners can also make a class newspaper with interesting topics such as famous jokes in English or famous proverbs that got mixed up, bloopers, curiosities, anything that would have them all involved.

- Dubbing for a silent video. Students can learn how to dub for silent videos by first having the teacher model. In pairs, they can come up with the most original dialogue to accompany the video and dub it in row. Or the teacher can record a real conversation as the material to be dubbed and then play it at the end of the activity.

- Recording. Recording personal projects can be another way of students using gadgetry for practising and learning the language. The teacher can ask them to record a dialogue in different locations, weather conditions, moods, intonations as homework, and then play them in class. Oscars can be awarded for best actor/location/intonation.

- Interviews. Students can be encouraged to take interviews, asking questions related to the English or American culture, and present it in class. 


\section{Blended learning}

We have seen, that, as long as creativity is put to work, a plethora of hands-on activities can be coined, and they can include using modern devices as well, but off-screen. Blended learning can be include as much of technology as the teacher deems right and attractive, and as much as hands-on activities that can balance technology and Internet use.

Depending on his or her training, but also on the willingness to be up-todate, a teacher usually has the means to do so in the majority of schools in Romania. If schools do not have ICT labs, a teacher can still use materials of the Internet in class and can work with audio files instead.

Also, other catchy and new possibilities of using the Internet in the English class are: international classroom pen palling through Skype as well as monthly exchange of video projects.

Another blended option would be the idea of "Edutainment", that is, educational games, which some teachers have already tried. The next step is to invent digital games, with the help of tutorials, to serve the educational purposes and aims they set within the area of their subject.

Reading and writing could be encouraged through incentives in the form of book reports posted on blogs open to public appreciation. Another option could be collaborative writing: creating a class series which can be published.

Finally, teachers are responsible with helping students realize the pluses and minuses of vital aspects of today's society. Internet Awareness Projects can be projects to be organized and carried out by teachers and students alike, through the gathering of results of reports, studies, dangers, limits, personal solutions. Emotional Awareness Projects, on how emotions are connected to Internet usage and how to handle both emotions and Internet usage, can give students consistent thought for food and practice.

As a conclusion, we have seen that the Internet, as the widest store of information offers a colourful palette of digital solutions to help teachers of English adapt not as much to the trends in education but to the reality of growing generations of "wired" students, who do not know any other simpler language but the complex one of the Internet, since they are born in a more and more advanced and complex world.

\section{Conclusions}

The shift to a modernized technological world is continues, and the Internet is becoming more and more engrained in our and our students' lives, whether we desire it or not. Studies have proved that technology and the Internet help in academic achievement. But all that is technology related has also limits, to which the risks of superficiality or addiction should be added. 
Teaching through using ICT has its own costs and gains, and much can still be argued as to which weigh more, but, in the end, it is up to the teacher to weigh them and test whether they have a positive or a negative impact on students.

Tim Berners-Lee, the person responsible for setting the foundation stone of the WWW, considers that the Web and the Internet is what we make it, as it reflects humanity and it belongs to humanity. We have to teach today's generation of children and students how to judge information, since no on has copyright or censorship authority for the information posted. He is optimistic about the future of the Web. What about the future of the Web in education? Or in English teaching? These are questions each of us will need to answer, and this paper has offerred insights into the topic, so as to help with the answering.

Journalist Jeffrey R. Young stated in How Social Networking Helps Teaching (and Worries Some Professors) that it was shown that some professors would use new technologies just because they seemed cool, rather than for any specific learning goal. He comments:

„Technology is a good servant and a bad master; there's no substitute for excellence in teaching. At one end you have the professors who still have to have a student come up and show them how to get that image or video up on the screen, and who don't use e-mail; at the other, the professors who really only see the technology and who are willing to spend most of their work time fiddling with it. Somewhere inbetween are the professors who really stop to ask whether any given technology will actually enhance their teaching goals - and be honest about the answer."

In conclusion, what teachers are to retain is that technology is only a tool and it is them that have to realize how it can be leveraged to their and their students' advantage, while counting the risks. Finally, since technology belongs to the human kind and mind and is considered to be its most powerful tool, I have chosen to close with what writer, educator and philosopher C. S. Lewis reveals about power, powers and men:

"Each new power won by man is a power over man. Each advance leaves him weaker as well as stronger. In every victory, besides being the general who triumphs, he is also the prisoner who follows the triumphal car" (419). 


\section{Works cited}

"Key Data on Learning and Innovation through ICT at School in Europe 2011. ec.europa." EACEA P9. Eurydice. 2011. Web.10 June 2013.

"Learning in the 21st Century: Digital Experiences and Expectations of Tomorrow's Teachers." Project Tomorrow. 2013. Web. 18 May 2013.

Ashe, Paul. "Gadgets Galore." English Teaching professional. Issue 50. London: Pavilion Publishing Ltd, 2007. Print

Carr, Nicholas. The Shallows: How internet is changing the way we think, read and remember. London: Atlantic Books, 2010. Print

Crystal, David. Language and the Internet. Cambridge University Press, 2004. Web. 18 May 2013. Print

Dorman, Jennifer. Learning in the 21stCentury. Slideshare. 25 Jan 2013. Presentation

Herring, James. The internet and information skills. London: Facet Publishing, 2004. Print

Lewis, C. S. The Abolition of Man. London: HarperCollinsPublishers, 2002. Print

Lewis, Gordon. The Internet and Young Learners. Oxford University Press, 2004. Print

Oblinger, Diana, James L. Oblinger, ed. Educating the Net Generation, Educause, 2005. Web. 18 May 2013.

Prensky, Mark. "Digital Natives, Digital Immigrants." On the Horizon. NCB University Press. 2001. Web. 20 Mar. 2013

Rubin, Jason. "Tim Berners-Lee on the Future of His Invention." Emc. EMC Corporation, 2009. Web. 18 May 2013.

Smith, David Gordon and Erich Baberowsky. Teaching English with Information Technology. How to use the internet and IT when teaching-for the professional English language teacher. London: Modern English Publishing Ltd, 2005. Web. 19 June 2013

Young, Jeffrey R. "How Social Networking Helps Teaching (and Worries Some Professors)". The Chronicle of Higher Education. 22 July 2010. Web. 18 May 2013. 